\title{
Bibliographic Access for Microform Collections
}

\begin{abstract}
Bibliographic access to individual titles in microform collections is a problem. Neither the Library of Congress nor most micropublishers fully analyze these collections. Individual libraries cannot afford to do so either. But without author and title access, these collections are not very useful. Full analytics for microform collections have been called for but no effort yet has been successful. The author suggests that libraries abandon full cataloging in favor of indexing, using the information provided by micropublishers. While a national index to the contents of microform collections would be best, an alternative for local libraries would be to create their own COM index.
\end{abstract}

\section{$\mathrm{P}$} ROVIDING bibliographic access for microcroforms reproduce monographs, serials, or government documents, they can be cataloged like the original. But because micropublishers are producing collections on microform containing hundreds or thousands of individual titles, bibliographic control has become almost impossible. ${ }^{1}$ The problem is that "all the items are effectively hidden from discovery by users unless a separate card, or analytic, is filed for each one." 2 Yet most libraries have been unable to provide such control. E. Dale Cluff found that "most libraries are handling major microform sets on an ad hoc basis." ${ }^{3}$ They are not fully cataloging individual items in a microform collection, but rather are treating the collection as a single work. ${ }^{4}$

Libraries are not fully analyzing their microform collections partly because the Library of Congress does not. Gloria Hsia, chief of the Cataloging Publications Division at LC, says that "the Library simply does not have the staff resources to prepare the analytics that are so desirable for such sets." ${ }^{\text {No }}$ individual library has sufficient staff either to fully catalog microform collections. June Thompson, in her study of eighteen Canadian university libraries, found that "the

Ann Niles is assistant college librarian, Carleton College, Northfield, Minnesota. number of titles in a single collection can be almost as large as the yearly book intake of some of the reporting libraries." 6

Sometimes micropublishers provide catalog cards, but libraries often do not use them because of filing costs and limited catalog space. ${ }^{7}$ Another reason libraries are reluctant to use these cards is that they require "extensive revision and it is indeed questionable if a library should provide either the card catalog space or the personnel needed to revise and file such cards." 8 Probably because libraries are not buying their cards and because of the expense of producing them, most micropublishers are not providing catalog cards for their collections. Of the eighty-one microform projects reviewed by Microform Review in 1978 , only six had cards.

Without access to individual items, important material contained in these large microform collections will not be read "simply because [users] will never know what is in them." ${ }^{9}$ What C. Edward Carroll found for research materials is that "in those libraries where control is more complete, that is, where microforms are cataloged in the same manner as are other library materials - the use is equal to the use of other materials." 10

Since most libraries are not fully cataloging their microform collections, reference librarians have improvised. In the absence of traditional bibliographical control, "the burden of informing library users of the avail- 
ability of microform collections has fallen on reference librarians." 11 At the University of North Carolina-Chapel Hill (UNC) the reference librarians have compiled two notebooks to assist them in providing information on the library's holdings in microform. One notebook, "Microform Series: A Guide to Collections and Series in Microforms," lists the general title of the collections, the source, entry in the card catalog, if author/title analytics are filed, bibliographical tools of assistance, and call number. The second, "Microforms: Listings of Titles in Series," contains titles of individual items for some of the collections from packing lists, catalogs, brochures, or typed lists. The problem with this approach is that the information is not complete for every collection and each collection has to be consulted to locate an individual title. This is a time-consuming way to determine if a title wanted is held in a microform collection.

Fully analyzing microform collections has been proposed for the past seventeen years. In 1962 Wesley Simonton, following his study of bibliographic control of microforms, recommended that "every effort be made to develop cooperative or centralized analytic cataloging for multiple-title micropublishing projects."12 Felix Reichmann and Josephine Tharpe echoed his conclusion in 1972. "The descriptive cataloging of microforms ... should be practically identical with the cataloging of the original except for notes identifying the item as microimage."13 Reichmann and Tharpe recommended that the Library of Congress should include analytics for microforms in the MARC project and that "a detailed cost and feasibility study of a machine-readable index for analytics of series in microforms should be made." 14 Their analytics are essentially full cataloging. "The basic bibliographic record for each title in the microsets contains . . . author headings . . . subjects . . . short title, editor or translator ... edition, imprint date, publisher, set number and item number within the set and unique number within the set."15

Sharing of analytic cataloging for microform collections has also been proposed. In 1974 E. Dale Cluff suggested that libraries that had fully cataloged their microform collections be identified so their cataloging could be made available to other libraries. A more successful attempt to provide information about completed cataloging for microform collections is the METRO Survey by William Myrick. This survey of the New York Metropolitan Reference and Research Agency and ARL members lists the guides to microform collections that members have produced. METRO is also serving as a clearinghouse for other libraries to make known their cataloging for microforms. ${ }^{16}$ And in the fall of 1978 the ARL Task Force on National Library Network Development proposed to the ARL Board that an office in ARL be created "for a three year period to organize and coordinate a national program which would develop a cooperative program for retrospective cataloging of microforms." 17

The problem with these approaches is the assumption that microform collections must be fully analyzed. While it is evident that access to individual items in microform collections is essential, it may not be possible to describe completely each item. The sheer volume of these collections has prevented the $\mathrm{Li}$ brary of Congress, micropublishers, and academic libraries from fully cataloging them. No library has the staff, which in some cases might have to be doubled, to put the collection on a microform reader, establish the main entry, assign subject headings, and describe each work. The need for additional catalog cabinets has also inhibited full cataloging. Perhaps, then, it is time to reexamine our approach of full analytic cataloging for microform collections.

I suggest that cataloging be abandoned for indexing. While full cataloging is expensive, indexing could be done easily and quickly because most micropublishers already provide this information. Robert Asleson observed that "more and more micropublishers are constructing and publishing indexes which add value to the film copy by making access easier."18 This conclusion is supported by an examination of the microform projects evaluated by Microform Review in 1978. Of the eighty-one projects reviewed, guides or bibliographies were available for fifty-five. Those projects for which guides were not available were catalogs, bibliographies, dictionaries, documents, and manuscripts for which guides may not be appropriate or were on microfiche that had eye-legible headers. Micropublishers are providing guides because 
they are aware that their indexing is "an important sales tool" from which "the end user may . . . benefit."19

Librarians are also encouraging micropublishers to provide bibliographical information by refusing to purchase collections without it. ${ }^{20}$ Robert Grey Cole advises that "if essential internal and external bibliographical controls are not provided for specific micropublications, then libraries should not buy them." ${ }^{21}$ Librarians agree that it is the responsibility of micropublishers to supply indexing. Robert Blackburn believes that "the company or the institution responsible for the reproduction of the collection should issue with the reproduction as part of the cost, a bibliography or list of the items represented in sufficient fullness to be adaptable to the individual needs of each purchaser." ${ }^{22}$ It seems likely, then, that micropublishers will continue to provide indexing to their collections because librarians expect it.

But the problem with the indexing supplied by the micropublishers is that it needs to be put into some order. There is no comprehensive author or title index to the individual items for all collections. Consequently, in trying to locate a particular item in a collection, reference librarians may have to look through several publishers' catalogs, guides, or brochures. Without an author-and-title index, acquisitions staff cannot easily determine if an out-of-print book they are trying to obtain is already held in the collection in a microform edition. The same problem exists for interlibrary loan staff. Some of the material being borrowed from other libraries may be held in a microform collection in the library, but it is too time-consuming to try to verify this. Collection development staff, too, in trying to determine whether certain materials should be purchased, would find it useful to know what is already held in microform. Both librarians and users need an index to items in microform collections, and this would be little more than an organization of the bibliographical information supplied by the micropublishers.

The most comprehensive index would be one that included all of the microform collections that have been published. The model for such an index could be Baer's Titles in Series. Some collections could be excluded from the index. Collections based on stan- dard bibliographies could be listed with a note to consult the bibliography for information on the contents. Collections of government documents, ERIC documents, and similar collections that are already indexed could also be excluded. This index could have three parts: an author index, a title index, and an index under the general title of the collection where the contents of each collection would be listed. An entry could include author, title, original date of publication, title of the collection, and reel or microfiche number. The index could be annotated by reference staff to give call numbers for those collections held in the local library.

An index to the contents of microform collections would have the greatest value if it could be produced nationally and updated regularly. A logical publisher of such a tool is Microform Review, Inc., already producing Microform Review, Guide to Microforms in Print, and Microform Publishers Trade List Annual. The first edition of the index might include only those collections, according to some definition, contained in Microform Publishers Trade List Annual. Subsequent editions could be expanded to include older collections, and libraries could be encouraged to supply Microform Review, Inc., with their lists and guides prepared for those collections.

The production of such an index could be aided if micropublishers adopt standards for the information they provide in their guides and bibliographies. In 1977, the Subcommittee on Bibliographical Control of Microforms of the Micropublishing Committee of ALA proposed that "a strategy for bringing microforms into the national system for bibliographic control of library materials .... include ... establishing standards for the format of bibliographic information to be included in commercial listings of microforms." ${ }^{23}$ The ARL Task Force on National Library Network Development has also proposed that "the bibliographic control of microforms provided by publishers" 24 be improved. If microform publishers could be encouraged to produce their guides according to standards and in machine-readable format, then the production of an index would be much easier. Such an index may itself encourage more micropublishers to provide guides so that their collections will be 
indexed. Whether or not a collection is included in the index might be a considerable factor affecting the sales of microform collections.

Like all national solutions to bibliographical control of microforms, the production of such an index will take a long time to implement or may never occur. In the meantime, libraries have to turn to local solutions. By using information already available in the library, it should be possible for many libraries to create a local index to the contents of their microform collections similar to that for serial holdings. At the University of North Carolina-Chapel Hill, information for such an index is contained in notebooks in humanities reference listing contents of many microform collections; on analytic cards in the shelflist for several microform collections; and in bibliographies and guides provided by microform publishers. Excluding those collections based on a standard bibliography that provides contents information, ERIC and government documents that have their own indexing, and periodicals and newspapers that are included in the serials list, about forty-two already-cataloged microform collections at UNC could be included in such an index. Of the nineteen collections at UNC not yet cataloged, fourteen have guides or bibliographies giving contents information. One of the collections without a guide is a bibliography, and a contents listing may not be needed. The remaining four collections are on microfiche and the contents are available from the eye-legible headers.

A COM catalog would be an easy and efficient way to make the contents of microform collections known to library users and staff. The idea of a COM catalog listing the individual items in microform collections is not a new one, though earlier proposals called for full analytic cataloging. In 1972 Reichmann and Tharpe proposed that a study "of a machine-readable index for analytics of series in microforms should be made." 25 In 1978 Carroll reaffirmed this: "I suggest that we consider going to a COM catalog while we wait further developments in on-line systems." 26

To produce a COM catalog of the contents of microform collections for a library like UNC, it would be necessary to obtain a terminal, to arrange for the use of programmer time, computer time, and COM equipment at the campus computer center and to provide student or clerical time at the library to input the records at the terminal. Records for the contents could initially include only six pieces of information: author, title, general title of the collection, original date of publication, call number, and microfiche or reel number. However, they should be input in a MARC-compatible format so that if full analytic cataloging records became available, the contents records could be more easily upgraded and integrated with an online database.

Staff time devoted to bibliographic control of microforms for the library as a whole may not increase with the production of a COM catalog. Inputting the contents records that basically would be transcribed from information provided by publishers' guides, bibliographies, and catalogs could be done by student or clerical staff. Perhaps this could be a joint project between reference and cataloging departments. Some professional time may be needed for analyzing a few collections and for editing the COM catalog. But time spent by reference librarians in trying to locate materials on microform for users, and time spent by acquisitions, interlibrary loan, and collection development staff in trying to determine if the library holds particular items on microform, should be substantially reduced with an author-and-title index to microform collections.

\section{REFERENCES}

1. William J. Myrick, “Access to Microforms: A Survey of Failed Efforts," Library Journal 103:2301-4 (Nov. 15, 1978).

2. Marcia Jebb, "Bibliographic Control of Microforms," Drexel Library Quarterly 11:33 (Oct. 1975).

3. E. Dale Cluff, "Determining National Interest and/or Activity Relating to Bibliographic Ac- cess of Microforms," Microform Review 4:269 (Oct. 1975).

4. C. Edward Carroll, "Bibliographic Control of Microforms: Where Do We Go from Here?" Microform Review 7:321-26 (Nov.-Dec. 1978); Myrick, "Access to Microforms," p.2301-4; Cluff, "Determining National Interest," p.266-9; June Thompson, “Catalog- 
ing of Large Works on Microform in Canadian University Libraries," in Albert James Diaz, Microforms in Libraries (Westport, Conn.: Microform Review, Inc., 1975), p.128-36.

5. Gloria Hsia, "Library of Congress Contribution to the Bibliographic Control of Microforms," Microform Review 6:13 (Jan. 1977).

6. Thompson, "Cataloging of Large Works," p. 135.

7. Myrick, "Access to Microforms," p.2301-4; Thompson, "Cataloging of Large Works," p. 128-36.

8. C. Edward Carroll, "Some Problems of Microform Utilization in Large University Collections," in Albert James Diaz, Microforms in Libraries (Westport, Conn.: Microform Review, Inc., 1975), p.278.

9. Robert Grey Cole, "Bibliographic Control," Illinois Libraries 58:211 (March 1976).

10. Carroll, “Bibliographic Control,”p.322.

11. Cole, "Bibliographic Control,”p.215.

12. Wesley Simonton, "Bibliographic Control of Microforms," in Albert James Diaz, Microforms in Libraries (Westport, Conn.: Microform Review, Inc., 1975), p.264.

13. Felix Reichmann and Josephine Tharpe, Bibliographic Control of Microforms (Hamden, Conn.: Greenwood, 1972), p.31.

14. Ibid., p.32.

15. Ibid., p.42.
16. Carroll, “Bibliographic Control,” p.323-25.

17. Minutes of ARL meeting held in Washington, D.C. (Oct. 1978).

18. Robert Asleson, "Micropublishing," Drexel Library Quarterly 11:44 (Oct. 1975).

19. Allan B. Veaner, "Microform and the Library: A Retrospective," Drexel Library Quarterly 11:11 (Oct. 1975).

20. Stephen R. Salmon, "User Resistance to Microforms in the Research Library," in Albert James Diaz, Microforms in Libraries (Westport, Conn.: Microform Review, Inc., 1975), p. 387.

21. Cole, “Bibliographic Control,”p.216.

22. Thompson, "Cataloging of Large Works," p. 132 .

23. "A Proposal to the National Endowment for the Humanities and/or the Council on Library Resources, and/or National Commission on Libraries and Information Science," mimeographed (Subcommittee on Bibliographic Control of Microforms, ALA Micropublishing Committee, 1977).

24. Minutes of ARL meeting held in Washington, D.C. (Oct. 1978).

25. Reichmann and Tharpe, Bibliographic Control of Microforms, p.32.

26. Carroll, "Bibliographic Control,”p.323. 


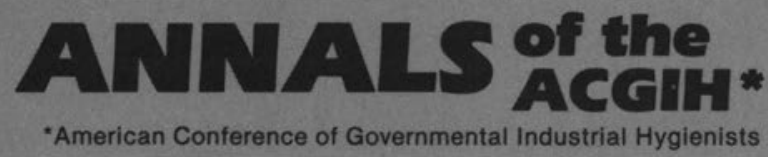

available Fall, 1981...

Volume 1-DOSIMETRY FOR CHEMICAL AND PHYSICAL AGENTSoverview of chemical and physical aspects/monitoring and reporting to meet regulatory requirements/passive monitors/physical agents/instrumentation. ACGIH Topical Symposium, October 6-8, 1981.

\section{scheduled for early '82...}

Volume 2-AGRICULTURAL RESPIRATORY HAZARDSCoverage includes cotton/agents, metabolites, environments/infectious and immunologic agents, dusts/grain dusts. Proceedings of an ACGIH Topical Symposium, held January 13-15, 1981. Page count and price to be announced shortly....call or write for details.

\section{to be released soon...}

Volume 3-HEALTH SERVICES FOR SMALL PLANTS - health protection litigation/key issues/provision of health services/noise, chemical hazards/injuries/ alcoholism, drug abuse/mental health. ACGIH Topical Symposium, October 26-28, 1981. Available Fall ' 82

Volume 4-PROTECTION OF THE SENSITIVE WORKER-defining, recognizing the sensitive individual/occupational exposure limits/employer-employee relations/legal, ethical issues. ACGIH Topical Symposium, November 9-11, 1981. Available Fall ' 82.

\section{about the ANNALS series...}

An important aspect of ACGIH activities is the sponsoring of an ongoing series of topical symposia on subjects of current importance to occupational safety and health professionals. Reflecting the latest state-of-the-art information available, the papers and discussions presented at ACGIH symposia and others of comparable merit, will be published periodically as a series of ANNALS of the ACGIH. All will be libraryquality books, with hard covers. Page counts and prices will be announced in advance of availability dates.

\section{about ACGIH...}

Organized in 1938, ACGIH members are professional personnel in governmental agencies or educational institutions engaged in occupational health and safety programs. The work of its committees and its publications are recognized and respected worldwide, as are ACGIH expertise and contributions to the improvement of occupational health and safety standards.

\section{START YOUR ANNALS of the ACGIH COLLECTION NOW!!!}

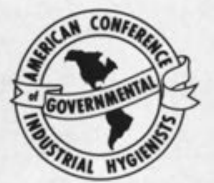

library discounts offered $\bullet$ subscription agency inquiries invited

PUBLICATIONS SECTION, ACGIH Dept. K, 6500 Glenway Ave., BIdg. D-5, Cincinnati, OH 45211 (513) $661-7881$

Send more information on the new ANNALS of the ACGIH series...

name

affiliation

address

city

state

zip

09281-K 


\title{
Humanities Index
}

\section{Your Guide to the Periodical Literature of the Humanities}

\author{
"An index for the liberal arts that serves \\ school, public, and undergraduate li- \\ brary needs..." \\ American Reference Books Annual
}

- Increased Coverage

- Easy Access to Information - International Coverage
- Accurate Subject Indexing

- A Voice in Indexing Coverage

Humanities Index offers librarians, teachers, researchers, and students up-to-date and extensive coverage of periodicals in the broad field of the Humanities. Recently studied and expanded from 245 to 299 periodicals, the Index covers periodicals that range from major journals, such as The Paris Review, to specialized journals, such as the Journal of Ecumenical Studies.

Entries in Humanities Index are arranged by author and subject in a single alphabet. Original works of fiction, poetry, and drama are indexed, as well as traditional and contemporary subjects, including:

Archaeology

Classical Studies

Folklore

History

Journalism
Language

Literary and Political Criticism

Performing Arts

Philosophy

Religion and Theology

Extensive cross-references, verification of personal names, and a listing of book review citations further aid research.

Humanities Index is published quarterly, with permanent bound annual cumulations. Sold on the service basis rate. For more information, please write to: Dept. 99

\section{The H. W. Wilson Company}

950 University Avenue, Bronx, New York 10452 